\title{
Moral Philosophies Underlying Ethical Judgments
}

\author{
Maheran Zakaria (Corresponding author) \\ Accounting Research Institute, Universiti Teknologi MARA \\ 44500 Shah Alam, Selangor Darul Ehsan, Malaysia \\ Tel: 60-9-762246 E-mail: maher835@kelantan.uitm.edu.my \\ Norhaini Mat Lajis \\ Academy of Language Studies, Universiti Teknologi MARA \\ 18500 Machang, Kelantan Darul Naim, Malaysia \\ Tel: 60-9-762252 E-mail:nml6338@kelantan.uitm.edu.my
}

$\begin{aligned} & \text { Received: December 27, } 2011 \quad \text { Accepted: February 1, } 2012 \quad \text { Published: April 1, } 2012 \\ & \text { doi:10.5539/ijms.v4n2p103 }\end{aligned}$ URL: http://dx.doi.org/10.5539/ijms.v4n2p103

\begin{abstract}
The purpose of this study is to examine the influence of moral philosophies namely deontology and teleology on ethical judgments. Deontology is evaluations made by referring to a set of predetermined rules and guidelines. On the other hand, teleology is evaluations made based on the consequences. Three hypothesized relationships were tested using a sample of 424 business students from 4 public institutions of higher learning in Malaysia. Based on the results of regression analysis SPSS 16.0, it can be concluded that both deontology and teleology were found to have a significant positive effect on ethical judgments. In addition, deontology was more likely to be used as opposed to teleology in the formation of ethical judgments. Hence, the findings of this study emphasize the importance of usage of these moral philosophies among future businessmen in enhancing ethical judgments.
\end{abstract}

Keywords: Deontology, Teleology, Business student, Ethical judgment

\section{Introduction}

The primary goal and the motivating force for business firms are to make as much profit as they can. However, too much focusing on profit can lead firms to totally pursue their own interests without consideration of ethical issues, which could end up with disasters. This has been evidenced by several unethical practices of business operators recently reported. For example, in China, a food producer, namely Sanlu Group Company, was found selling infant milk formula which was tainted with the chemical melamine (The Star, 23 January 2009). As a result, at least six babies died and nearly 300,000 fell ill. Melamine has been used by manufacturers as a low-cost way of enriching their product in both protein count and taste (Brook \& Dunn, 2008). The adverse effect of melamine is that it could damage kidneys. In Malaysia, surveys done by Consumer Association of Penang (CAP) from 1984 to 2008 found the presence of boric acid in various samples of food products tested, in spite of the prohibition of its use in food as stated under the Food Regulation Act of 1985 (The Star, 10 February 2010). Boric acid is so toxic that even when consumed in small amounts can lead to gastrointestinal poisoning, illness, kidney damage and loss of appetite. In 1988 it was associated with the death of 13 children and an adult in Perak (The Star, 2 February 2010). Such incidents indicate the extent and the prevalence of unethical behavior among business operators. They compromise moral value, and at worst human lives, for the sake of profit.

Actually, the success and the survival of a business do not only depend on profit, but also the degree to which the business can balance both profit and interest of the public (Brook \& Dunn, 2008). Therefore, apart from maximizing shareholders' wealth, the businesses also have moral and social responsibilities towards the public. The businesses need the public support, for which in return they should offer goods and services that are safe and of high qualities. However, the incidents mentioned above are indications that the business operators are doing otherwise. They are only concerned in making profits instead of acting in the best interests of the public. Ironically, such incidents have eroded the business' credibility and reputation. These incidents also consequently 
spurred the interest of many scholars and researchers to investigate why business operators are unethical in their practices and judgments.

Ethical judgments are judgments by which an individual, who is facing an ethical dilemma, evaluates the ethical problems, consider alternatives and choose an alternative that best solves the problem to attain the most beneficial outcomes (Fang, 2006). In addition, the judgments are formed after weighing all the considerations of what are morally right and wrong in the context of acceptable standards (Marta, 2004). Philosophers have studied a variety of standards and business ethicists have built the appropriate standards in their work. The General Theory of Marketing Ethics proposed by Hunt and Vitell (1993; 1986), include the moral philosophies, which flowed from the philosophical moral theory of deontology and teleology. These two moral philosophies are cognitive style applied by an individual as evaluations before the formation of ethical judgments.

Deontology emerges from the Greek term deon, which means necessary or obligatory. This theory has been established in western moral philosophy that receives the influence of prominent Greek moral philosophers, such as Socrates and Plato, and the very influential German philosopher, Immanuel Kant (1724-1804) (Marta, 2004). The theory states that the only unqualified good is a good will. A good will manifests itself when it acts for the sake of duty, where duty implies a recognition and adherence to a law or precept.

Teleology was coined from a Greek term telos, which means ends, consequence and results. This theory evaluates ethical actions in terms of their contribution and consequences of the judgments, rather than their conformation to rules or commandment (Finnis, 1998). The fundamental difference between the two theories lays on that deontology theory focuses on the ethical character of an act. An act is considered ethical based on motivation and duty of the decision-maker. It is the duty of the decision-maker to comply with rules and procedures, irrespective of whether the decision would produce good consequences. The drawback of deontology is that it only focuses on motivation and the duty of the decision maker and ignores the consequences derived from the judgments.

On the other hand, teleology theory postulates that an action is ethically correct if it produces a net balance of good over evil for the decision maker or society as a whole. Unethical action is sometimes considered good if it provides the greatest good over evil to the majority of stakeholders, irrespective of rule compliance. However, the drawback of using teleology is that the decision maker must take a broad perspective concerning who might be affected by the decisions and choose the judgments that promote pleasure and alleviate pain and suffering. In addition, breaking the law is allowed, if it could bring more goodness than badness. However, neither deontology nor teleology can stand alone. Both theories are needed to produce a comprehensive ethical judgment. This makes a useful complement to each of the theory, because an action that satisfies both theories can be said to have a good chance of being ethical.

Many factors are predicted to influence ethical judgments, and one of the factors is the moral philosophies that consist of deontology and teleology (Hunt \& Vitell, Theory of Ethics 1993; 1986). Previous studies have documented that these moral philosophies influence ethical judgments (Donoho et al., 2009; Cherry \& Fraedrick, 2007; Marta, 2004). As a response to the problem of ethical issues, this present study likewise was triggered by the unethical happenings mentioned above. It will examine the factors of ethical judgments. Despite the fact that ethics is a worldwide issue, majority of the prior studies were conducted in the western while local study remain scarce. In addition, as believed by many, future leaders are developed in today's classrooms (Malone, 2006). As such, this study intends to investigate these factors using business students who are expected to be the future businessmen. In this regards, this study aims to investigate the following objectives:

1). The relationship between deontology and ethical judgments.

2). The relationship between teleology and ethical judgments.

3). The usage of deontology as opposed to teleology in the formation of ethical judgments.

\section{Methodology}

\subsection{Data Collection}

The study used survey for data collection in which data were collected through questionnaires. The questionnaires were distributed to business students from 4 public universities namely Universiti Teknologi MARA, Universiti Sains Malaysia, Universiti Kebangsaan Malaysia and Universiti Putra Malaysia. Business students were chosen because they are expected to be future business operators and their responses are of great use for future businesses. Of the 500 respondents to whom questionnaires were sent, 450 responded with the response rate of $90.0 \%$. However, only 424 questionnaires were usable for the analysis. The non-usable questionnaires were due to incomplete response to all the 3 scenarios. Hundred and twenty were late response 
because their questionnaires were received one month after the set deadline. A comparison of the responses from the early and the late respondents suggests that there is no significant difference in the results between the two respondents' groups.

\subsection{Operationalisation of Variables}

The study examines one dependent variable (ethical judgments) and two independent variables namely deontology and teleology. All variables namely ethical judgments, deontology and teleology are measured based on the respondents' response to three ethical business scenarios. The scenarios are withholding information, selling defective products and deceptive advertising adopted from the study carried out by Marta (1999). Adaptations were also made to suit the local environment. These three variables are discussed in the following sections.

Ethical Judgments are measured through one item based on three similar scenarios that measured deontology and teleology. The respondents are required to rate each of the 3 scenarios. (Please rate the action as to how ethical you believe it was, measured on a seven-point Likert-type scale ranging from very ethical (1) to very unethical (7)]. A high score indicates a respondent is more likely to perceive that the scenario is unethical or more likely to form ethical judgments. On the other hand, a low score indicated that a respondent is less likely to form ethical judgments (respondent perceives the situation as ethical). The scores of the three scenarios are added and divided as to get the mean values for the construct. This measurement is similar with previous studies on ethics (Md. Zabid \& Saidatul, 2008; Marta, 2004; Singhapakdi et al. 1994; Hunt \& Vasquez-Parraga, 1993; Singhapakdi \& Vitell, 1993).

Deontology and Teleology are measured by using the three similar scenarios that measured ethical judgments. There are six statements following each of the scenarios. Three of the statements consisted of applicable deontology while the remaining three represented teleology. Respondents are instructed to rank these six statements, by giving the highest score of 100 to the statement that they think provided the most important reason. They are then required to allocate the score to the five remaining statements of less than 100 in reducing values depending on the importance of the reasons to each particular statement. Next, the score is adjusted to a 7 point scale, as to be consistent with the other scales of variables in this study. Finally, this study performed multiple regression of Statistical Package for Social Science (SPSS) 16.0 to examine i) the relationship between deontology and teleology with ethical judgments, and ii) the usage of deontology as opposed to the teleology in the formation of ethical judgments.

\subsection{Development of the Hypotheses}

Deontologists believe that a judgment is right if the features of the act itself are right, irrespective of the consequences the act may bring about (Jung, 2002). According to the deontologists, a judgment is formed based on motivation, duty and obligation. The duty and obligation of the decision-maker is to adhere to a set of rules and guidelines (Macdonald \& Back-Dudley, 1994). Therefore, the ethicality of judgment is evaluated based on motivation and duty of the decision-maker (Brook \& Dunn, 2008).

Several studies have been carried out to investigate the influence of deontology on ethical judgments indicating a significant relationship (Donoho et al., 2009; Cherry \& Fraedrich, 2007; Marta, 2004). When faced with ethical dilemmas, individuals who use deontology is expected to be more likely to form ethical judgments. They would form judgments based on motivation and duty that adhere to legislations, rules and regulations. As such, this study proposes the following hypothesis.

$\mathrm{H}_{1}$ : Deontology is positively related to ethical judgments.

Teleologists believe that individuals should assess the relative merits of all consequences of a particular behavior. Even breaking rules can be good in some situations and bad in others, as judgment on morality is established by consequences not by motive or the features of the behavior (Marta, 1999). Prior studies have investigated the influence of teleology on ethical judgments and indicate a strong relationship (Donoho et al., 2009; Cherry \& Fraedrich, 2007; Arnett, 2005).

When faced with an ethical dilemma, the individuals who evaluate problems based on teleology are expected to be more likely to form ethical judgments. These people would form judgments after evaluating the actions, with respect to the net goodness or badness of the consequences it effectuates. The judgment is considered ethical if it could provide the maximum happiness to the majority of the stakeholders. As such, this study proposes the following hypothesis.

$\mathrm{H}_{2}$ : Teleology is positively related to ethical judgments. 
As both of the theories are important for the formation of ethical judgments, the question that arises is, between deontology and teleology which of the two theories is more likely to be used. Previous studies have also examined the reliance of this moral philosophies either deontology or teleology on ethical judgments (Donoho et al, 2009; Cherry \& Faedrick, 2005; Marta, 2004) and indicated that deontology is more likely to be used as opposed to teleology in the formation of ethical judgments.

When faced with ethical dilemmas, it is expected that an individual who forms ethical judgments, is the person who would be more likely to evaluate problems based on deontology by referring to legislations, rules and standards as opposed to teleology that emphasizes on consequences of the decisions. As such, the following hypothesis is formulated.

$\mathrm{H}_{3}$ : Deontology is more likely to be used as opposed to teleology in the formation of ethical judgments.

\section{Results and Discussion}

\subsection{Profiles of Respondents}

The profiles of the respondents in this study are reported in Table 1. All information is presented in frequency and percentages to facilitate interpretation. Respondents consist of 142 males and 282 females. Two hundred and seventy four are Malays, ninety six are Chinese and the remaining fifty four are Indians.Meanwhile, 54 percent of the respondents are less than 20 years, 72.5 percent are between 21 to 30 years, while 14.7 percent are above 30 years. Finally, 301 or 71 percent of the respondents are high school leavers, 110 or 25.9 percent hold a bachelor degree and 13 or 3.1 percent have a master degree.

\subsection{Descriptive Statistics}

Table 2 presents the descriptive statistics of the variables under study. The mean values of the three variables are derived by averaging the scores obtained from the three scenarios. Results indicated that the mean value of ethical judgment is 5.53 out of 7.00 or equivalent to $79 \%(\mathrm{std}$. dev. $=1.55)$. While, the mean value of deontological evaluations is 5.81 out of 7.0 or $83 \%$ (std dev. 1.67). Finally, the mean value of teleological evaluations is 4.34 out of 7.0 or stood at $62.0 \%$ (std. dev. $=1.98)$. The study uses skewness and kurtosis to check any deviation from normality. The results showed that the values are in the range between positive one $(+1.0)$ and negative one $(-1.0)$. (The values which are not in the range between positive one $(+1.0)$ and negative one $(-1.0)$ are candidates for modification and elimination).

The study then performed explanatory factor analysis with varimax rotation and the results condensed all the three variables namely ethical judgments, deontology and teleology into one factor. This is consistent with the studies by Marta (2004) which indicated that these three variables had only one factor. All constructs showed eigenvalues larger than 1. The factor loadings for deontological evaluations were in the range of .82 to $.94, .73$ to .83 and .63 to .80 respectively. The reliability analysis of the variables indicated that the cronbach's alpha for deontological evaluations, teleological evaluations and ethical judgments were $.65, .85$ and .67 respectively, in which each has exceeded the recommended value of .60 (Sekaran, 2000; Nunally, 1978). The data from the sample were appropriate for factoring $(\mathrm{KMO}=.78)$, which have also exceeded the recommended value of .50 (Kaiser, 1974). Next, the results revealed that all of the nine items loaded had the factor loading scores of greater than .70. In addition, the items accounted for deontological evaluations, teleological evaluations and ethical judgments were $69.38 \%, 77.25 \%$ and $63.71 \%$ respectively. The principal component analysis indicated that only one component extracted for all the variables. No item therefore needed to be deleted and the data were submitted for further analysis. Table 3 presents the results of the analysis done on goodness of the data.

\subsection{Correlation Analysis}

Table 4 depicts the analysis of Pearson correlation between variables. The results show that there is a positive bivariate relationship between deontological evaluation and teleological evaluation with ethical judgments. The table also shows that the relationships among independent variables are relatively low. Hence, the multicollinearity problem is not the main concern here.

\subsection{Hypotheses Testing}

The hypotheses of the study are tested by using the multiple regressions (SPSS version 16.00). The ethical judgments are regressed against deontology and teleology evaluations. Table 5 shows that both deontology and teleology are positively related to ethical judgments $\left(\beta_{1}=.56, \beta_{2}=.35, p\right.$ value $\left.<.01\right)$. The results indicated that the $\mathrm{H}_{1}$ and $\mathrm{H}_{2}$ are statistically significant and in the hypothesized direction. 
In addition the results also supported $\mathrm{H}_{3},\left(\beta_{1}>\beta_{2}\right)$ that deontology evaluations are more likely to be used as opposed to teleology in the formation of ethical judgments. Apart from that, descriptive results indicated that the usage of deontology $(83.0 \%)$ is greater as opposed to teleology $(62.0 \%)$.

\section{Discussion}

The objective of this study is to examine the relationship between deontology and ethical judgments. Results show that future businessmen (business students) use deontology in the formation of ethical judgments. These findings are consistent with past studies (Donoho et al., 2009; Cherry \& Fraedrich, 2007; Marta, 2004) and supported the general theory of marketing ethics (Hunt \& Vitell, 1993; 1986) that moral philosophies are associated with ethical judgments.

Evidences have shown that most unethical judgments were formed by those who did not rely on deontology or rules based system. For example, in Malaysia, surveys done by CAP from 1984 to 2008 found that the presence of boric acid in various samples of food products tested, despite the fact that the use of boric acid in food is prohibited under the Food Regulation 1985. The inclusion of boric acid is the fast way to boost sales at a low cost. Although it is illegal, the business operators are still practicing it as they are motivated to make as much profit as they can.

The study also examines the relationship between teleology and ethical judgments. Likewise, the results indicate that future business operators use teleology in the formation of ethical judgments and the findings are similar to prior studies (Donoho et al., 2009; Zakaria et al., 2009; Cherry \& Fraedrich, 2007; Marta, 2004; Rallapalli et al., 1998).

According to teleologists, an action is ethical if it promotes the greater good for the majority of stakeholders. Evidences have shown that business operators perform unethical practices because they did not use teleological evaluations, for which they are more concerned of their own interest instead of the public. In other words, they are willing to compromise public health and safety for the sake of money.

Finally, the study examines the usage of deontology as opposed to the teleology in the formation of ethical judgments. The results reveal that the coefficient value from deontology to ethical judgments $(\beta=.56, \mathrm{p}<.01)$, is greater than the coefficient value from teleology to ethical judgments $(\beta=.32, \mathrm{p}<.01)$. Moreover, descriptive analysis also shows that deontology is more likely to be used as opposed to teleology evaluations. Hence, the findings are consistent with those of prior studies (Cherry \& Fraedrick, 2007; Marta, 2004; Rallapalli et al., 1998).

The present study has several limitations that need to be acknowledged. First, this study used a convenience sampling, therefore the results may not be able to generalize the ethical judgments of Malaysian business students' in public institutions of higher learning. The second limitation noted is the use of self-reported questionnaires, whereby respondents tended to rate themselves more ethical than they actually were. This self-deception bias is a common phenomenon in studies related to ethics and was not fully controlled in this research. However, this bias is a constant factor and it is unlikely to affect the validity of the results.

\section{Conclusion}

The study concludes that deontology and teleology have a positive relationship with ethical judgments. In addition, future business operators appear to use more deontology as opposed to teleology in the formation of ethical judgments. The study contributes important theoretical and practical implications to the ethics literature. The outcomes of this study suggest that institutes of higher learning need to educate their business students on the importance of adhering to rules and regulations (deontology). In addition, the students should be exposed to the importance of identifying who are the stakeholders who could be affected by the judgments and make judgments in the interests of the majority (teleology). The exposure will sharpen their ethical awareness and help to shape the desired ethical behaviors. Hence, the findings of this study are useful to the policy makers, government and higher learning institutions to create awareness of the importance of these two moral philosophies namely deontology and teleology on the formation of ethical judgments. Last but not least, it is hoped that the results will help these bodies to formulate policies and strategies that take into account these two moral philosophies thus enhancing ethical judgments of future businessmen.

\section{References}

Aaker, J.L. (1989). The malleable self: the role of self-expression in persuasion. Journal of Marketing Research, 36 (1). 45-57. http://dx.doi.org/10.2307/3151914 
Akaah, Ishmael. (1997). Influence of deontological and teleological factors on research ethics evaluations. Journal of Business Research, 39. 71-80. http://dx.doi.org/10.1016/S0148-2963(96)00143-9

Bentler, P.M., \& Bonet, D.G. (1980). Significance tests and goodness of fit in the analysis of covariance structures. Psychological Bulletin, 88. 588-606. http://dx.doi.org/10.1037/0033-2909.88.3.588

Bollen, K.A. (1989). A new incremental fit index for general structural equation models. Sociological Methods and Research, 17. 303-316. http://dx.doi.org/10.1177/0049124189017003004

Boomer, M., Gratto, J., Gravender, J., \& Tuttle, M. (1987). A behavioral model of ethical and unethical decision-making. Journal of Business Ethics, 6. 265-280. http://dx.doi.org/10.1177/0049124189017003004

Brook, L.J., \& Dunn, P. (2008). Business \& Professional Ethics for Directors, Executives \& Accountants (5th. Ed). Toronto: South Western Cengage Learning.

Cherry, J., \& Fraedrich. J. (2007). Perceived risk, moral philosophy and marketing ethics: mediating influences on sales managers' ethical decision-making. Journal of Business Research, 55 (12). 951-962. http://dx.doi.org/10.1016/S0148-2963(00)00215-0

China milk scam duo get death. (2009). The Star, 23 January, p.37.

Supplements can hurt you - and your pocket. (2010). The Star, 10 February, p.40.

25 years of inaction: Boric acid still in food. (2010). The Star, 2 February, p.33.

Fang, M. L. (2006). Evaluating ethical decision-making of individual employees in organizations - An integration framework. Journal of American Academy of Business, Cambridge, Hollywood, 8 (2), 105-113.

Finnis, J. (1988). Fundamental of ethics. Washington, DC: Georgetown University Press.

Geisler, N.L. (1990). Christians ethics: Options and issues. Grand Rapids: MI, Baker Book.

Hegarty, W.M., \& Sims, H.P. Jr. (1978). Some determinants of unethical decision behavior: An experiment. Journal of Applied Psychology, 63. 451-457. http://dx.doi.org/10.1037/0021-9010.63.4.451

Higgs, N.S., \& Kapelianis, D. (1999). The role of professional codes on regulating ethical conduct. Journal of Business Ethics, May. 36. 123-154.

Hunt, S.D., \& Vitell, S.J. (1986). A general theory of marketing ethics. Journal of Macromarketing, 6. 5-16. http://dx.doi.org/10.1177/027614678600600103

Hunt, S.D., \& Vitell, S.J. (1993). A general theory of marketing ethics: a retrospective and revision. In N.C. Smith \& J.A.Quelch (Ed.). Ethics in marketing, pp.775-784.

Jones, T.M. (1991). Ethical decision-making by individuals in organizations: An issue-contingent model. Academy of Management Review, 16 (2). 366-395.

Joreskog, K.G., \& Sorbom, D. (1984). Lisrel-VI user's guide ( $3^{\text {rd }}$ ed.). Scientific Software, Mooresville.

Kaiser, H. (1974). An index of factoral simplicity. Psychometrika, 39. 31-36. http://dx.doi.org/10.1007/BF02291575

Lazniak, Gene R., \& Murphy, P. (1993). Ethical marketing decisions: the higher road. Allyn and Bawn, Boston.

Lazniak, Gene R. (1983). Framework for Analyzing Marketing Ethics. Journal of Macromarketing, 3, 7-18. http://dx.doi.org/10.1177/027614678300300103

Macdonald, J.E., \& Back-Dudley, C.L. (1994). Are deontology and teleology mutually exclusive? Journal of Business Ethics, 13(8), 615-623. http://dx.doi.org/10.1007/BF00871809

Marta J.K.M., Singhapakdi A., Attia A., \& Vitell, S.J. (2004). Some important factors underlying ethical decision of Middle-Eastern marketers. International Marketing Review, 21 (1). 53 -67. http://dx.doi.org/10.1108/02651330410522916

Md. Zabid, R., \& Saidatul, I. (2008). The effect of culture and religiosity on business ethics: A cross-cultural comparison. Journal of Business Ethics, 82 (3). 907-917.

Mayo, M.A., \& Mark, L. (1990). An empirical investigation of a general theory of marketing ethics. Journal of the Accounting and Marketing Science, 18 (2), 163-171. http://dx.doi.org/10.1007/BF02726432

Marta, J.K.M. (1999). An empirical investigation into significant factors of moral reasoning and their influences on ethical judgment and intentions. Doctoral dissertation, Old Dominion University. [Online ] Available: http:/www.proquest.umi.com (July 4, 2006). 
Nunally, J.L. (1978). Psychometric Theory (2 ${ }^{\text {nd }}$ ed.). New York: McGraw- Hill.

Rallapalli, K.C., Vitell, S.J., \& Barnes, J.H. (1998). The influence of norms on ethical judgments and intentions: an empirical study of marketing professionals. Journal of Business Research, 43. 157-168. http://dx.doi.org/10.1016/S0148-2963(97)00221-X

Reidenbach, R.E., \& Robin, D. (1987). Social Responsibility ethics and marketing strategy: closing the gap between concept and application. Journal of Marketing, 51 (2). 44-58.

Rudelius, W., \& Buchholz, R.A. (1979). Ethical problems of purchasing managers. Harvard Business Review, 57 (8), 12-14.

Singhapakdi, A., \& Vitell, S.J. (1991). Analyzing the ethical decision making of sales professionals. Journal of Personal Selling and Sales Management, 11, 1-12.

Tsalikis, J., \& Fritzsche, D.J. (1989). Business ethics: A literature review with a focus on marketing ethics. Journal of Business Ethics, 8. 695-743. http://dx.doi.org/10.1007/BF00384207

Tucker, 1.R., Stathakopolous, V., \& Patti, C.H. (1999). A multidimensional assessment of ethical codes: the professional business association perspective. Journal of Business Ethics, 19. 287-300. http://dx.doi.org/10.1023/A:1005805103665

Verschoor, C.C. (1998). A study of the link between a corporation's financial performance and its commitment of ethics. Journal of Business Ethics, 17. 1509-1516. http://dx.doi.org/10.1023/A:1006020402881

Verschoor, C.C. (2005). Business and professional ethics for directors, executives and accountants (Eds). Internal Auditing, Boston.

Windsor, C.A. (2002). Auditors' predisposition to provide fair judgments: Australian evidence of auditors' level of moral reasoning. Australian Accounting Review, $12 \quad$ (2). 51-57. http://dx.doi.org/10.1111/j.1835-2561.2002.tb00203.x

Zakaria, M., Haron, H., \& Ishak, I. (2010). The Influence of moral philosophies, deontology and teleology on auditor's ethical judgments. Malaysian Accounting Review, 8 (1), 43 -65.

Table 1. Profile of respondents $(\mathrm{N}=424)$

\begin{tabular}{|l|c|c|l|c|c|}
\hline Item & Frequency & Percent & Item & Frequency & Percent \\
\hline Gender & & & Race & & \\
\hline Male & 142 & 33.5 & Malay & 274 & 64.5 \\
\hline Female & 282 & 67.5 & Chinese & 96 & 22.7 \\
\hline & & & Indian & 54 & 12.8 \\
\hline & & & & & \\
\hline Age than 20 & 54 & 12.8 & High school & 301 & 71.0 \\
\hline $\begin{array}{l}\text { Less years } \\
\text { 21 to 30 years }\end{array}$ & 308 & 72.5 & Degree & & \\
\hline Above 30 years & 62 & 14.7 & Master & 110 & 25.9 \\
\hline
\end{tabular}

Table 2. Descriptive statistics $(\mathrm{N}=424)$

\begin{tabular}{|l|c|c|c|c|c|}
\hline Variables & Mean & Percentage & $\begin{array}{c}\text { Standard deviation } \\
\text { (std.dev.) }\end{array}$ & Skewness & Kurtosis \\
\hline Ethical Judgments & 5.53 & 79.0 & 1.55 & -.46 & -.69 \\
\hline Deontology & 5.81 & 83.0 & 1.67 & -.39 & .71 \\
\hline Teleological & 4.34 & 62.0 & 1.98 & -.23 & -.58 \\
\hline
\end{tabular}


Table 3. Goodness of data $(\mathrm{N}=424)$

\begin{tabular}{|l|c|c|c|c|c|c|}
\hline Measure & Items & $\begin{array}{c}\text { Factor } \\
\text { Loading }\end{array}$ & KMO & Eigenvalue & $\begin{array}{c}\text { Variance } \\
\text { explained }\end{array}$ & $\begin{array}{c}\text { Cronbach's } \\
\text { Alpha }\end{array}$ \\
\hline $\begin{array}{l}\text { Deontological } \\
\text { evaluations }\end{array}$ & 3 & $.82-.94$ & .64 & 1.82 & $60.79 \%$ & .66 \\
\hline $\begin{array}{l}\text { Teleological } \\
\text { evaluations }\end{array}$ & 3 & $.85-.91$ & .71 & 2.31 & $76.85 \%$ & .85 \\
\hline $\begin{array}{l}\text { Ethical } \\
\text { Judgments }\end{array}$ & 3 & $.63-.80$ & .69 & 1.61 & $63.62 \%$ & .76 \\
\hline
\end{tabular}

Table 4. Correlation analysis

\begin{tabular}{|l|c|c|c|}
\hline Variables & $(1)$ & $(2)$ & $(3)$ \\
\hline 1.Ethical Judgments & 1.00 & & \\
\hline 2.Deontology & $.39^{* *}$ & 1.00 & .04 \\
\hline 3.Teleology & $.24^{* *}$ & .00 \\
\hline
\end{tabular}

$p<.05 *(2$-tailed $), \quad p<.01 * *(2$-tailed $)$

Table 5. Multiple regression results of deontology and teleology with ethical judgments

\begin{tabular}{|l|c|}
\hline Variable & Standard Beta \\
\hline Determinants of Ethical Judgments & $.56^{* * *}$ \\
\hline Deontology & $.35^{* * *}$ \\
\hline Teleology & .84 \\
\hline$R^{2}$ & .80 \\
\hline Adjusted $R^{2}$ & 49.18 \\
\hline F & .000 \\
\hline Sig & \\
\hline
\end{tabular}

$\mathrm{N}=424 . * p<.1, * * p<.05, * * * p<.01$ (two-tailed test).

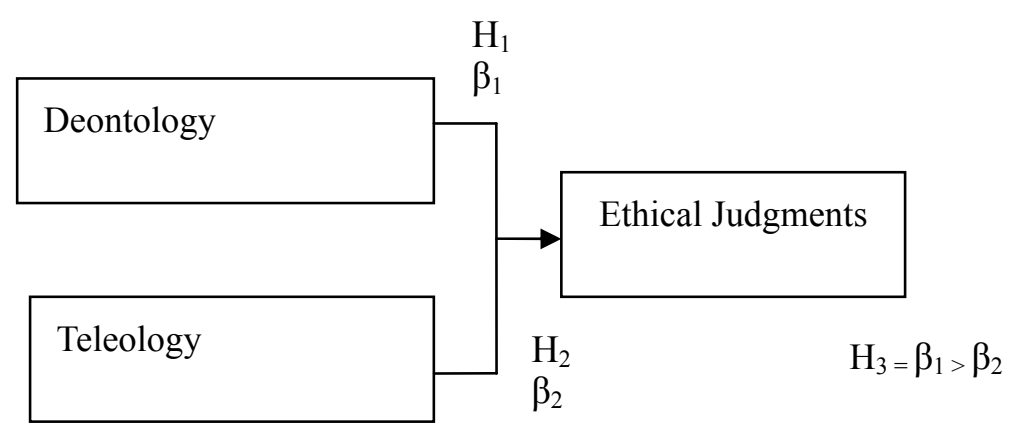

Figure 1. Proposed conceptual framework 